\title{
EFFECT OF CONJUNCTIVE USE OF WATER ON YIELD COMPO- NENTS AND MARKETABLE YIELD OF RADISH CROP
}

\author{
R.K. Isaac ${ }^{1}$, N. Swaroop ${ }^{1}$ and J.L.G. Kumar ${ }^{2}$ \\ ${ }^{1}$ Department of Soil Water Land Engineering and Management \\ Allahabad Agricultural Institute-Deemed University, Allahabad-India \\ ${ }^{2}$ Centre for Water Resources Research, University College Dublin, \\ Belfield, Dublin 4, Ireland
}

\begin{abstract}
Availability of irrigation water at reasonable cost is one of the most important factors for agricultural development. Conjunctive use of fresh and sewage water can successfully be adopted for cultivation. An experiment was laid out at the research plot of Allahabad Agricultural InstituteDeemed University, Allahabad, India in a randomized block design with three replications and four levels of sewage water i.e., $25 \%, 50 \%, 75 \%$ and $100 \%$ were applied to radish crop by blending with fresh water. It was observed that the higher level of sewage water significantly affected the vegetative yield of radish crop and provides maximum return at $100 \%$ sewage water. Plant height, root length, girth and yield of radish crop significantly increased with the increase of sewage content in the blended water. The blended water also increased the marketable yield of the radish crop. The fully sewage irrigated radish crop provided a net return of 3631.11US\$/ha with a benefit cost ratio of 7.96.The study shows the marketable yield and water use efficiency of radish crop increase with an increase in sewage water ratio. It was also observed that the presence of fungi and bacteria were remarkably lower at $50 \%$ and $25 \%$ sewage water irrigated crops.
\end{abstract}

Keywords: Conjunctive use, sewage water, marketable yield

\section{INTRODUCTION}

Water is considered a limited and vulnerable resource, essential for life. Currently agricultural land has become a disposal site for waste water. In this situation, waste water components can be used as an option to supply nutrients for crop growth productively. The main problem with waste water utilization for irrigation in agriculture, apart from the possibility of containing hazardous constituents, such as trace elements and organic compounds, is the risk of polluting ground water. Reuse of reclaimed water for irrigation enhances agricultural productivity, providing water and nutrients, and improving crop yields.

Waste water is used as a source of irrigation water since it serves as a source of plant nutrients. It allows farmers to reduce the use of chemical fertilizers. In many arid and semiarid countries, the scarcity of water is a real constraint but municipal sewage water can be considered as an integral part of irrigation supplies by blending with fresh water. Sewage must be treated to adapt it to agricultural uses, but treat- 
ment is also essential for safe environmental disposal, therefore, the relevant costs of waste water for agricultural reuse are just the additional costs needed for adaptation to agriculture. (sadan and Haruvy.1984). Benefits of agricultural reuse of waste water are expressed when agricultural production is maintained whilst water sources and environmental qualities are preserved.

The supply of waste water is determined by the density of population in a specified region, and this density also determines the prices of land in and or the availability of agricultural land in particular. To preserve environmental quality, surplus waste water should be disposed off to surface waterbodies, or conveyed to other locations for agricultural use.

\section{MATERIALS AND METHODS}

The present investigation was carried out in 2002 at Agricultural Institute-Deemed University; Allahabad, India $\left(25^{0} 27^{1} \mathrm{~N}, 81^{0} 44^{1} \mathrm{E}\right.$ and $98 \mathrm{~m}$ above mean sea level).The area is within semi and climatic zone. The average annual precipitation of the area is $600 \mathrm{~mm}$. The maximum and minimum temperatures of the area are $8^{\circ} \mathrm{c}$ and $23^{\circ} \mathrm{c}$ respectively.

The experiment was laid out in a randomized block design with three replications. Four levels off sewage irrigation water in conjunction with normal water at $25 \%$ sewage (Treatment $\mathrm{T}_{1}$ ), 50\% sewage (Treatment $\mathrm{T}_{2}$ ), $75 \%$ sewage (Treatment $\mathrm{T}_{3}$ ), $100 \%$ sewage (Treatment $\mathrm{T}_{4}$ ) were applied to the field. (Treatment $\mathrm{T}_{0}$ ) was considered as a control plot with $100 \%$ fresh water. The soil was loamy with average field capacity $19.55 \%$, average bulk density $1.46 \mathrm{gm} /$ $\mathrm{cm}^{3}$ and infiltration rate of $5.8 \mathrm{~mm} / \mathrm{h}$.

The crop was irrigated when sum of the daily mean of pan evaporation reached approximately to a predetermined value obtained by

Net irrigation requirement, $\mathrm{mm}$

$=\frac{\text { Rooting dept }(\mathrm{m}) \times \text { plant available soil moisture }}{(\mathrm{mm} / \mathrm{m}) \times \text { readily }}$

$(\mathrm{mm} / \mathrm{m}) \times$ readily available soil water in fraction
The measured quantity of tube-well water in conjunction with sewage water was supplied through the portable garden pipes from the water mixing tank by gravity.

\section{RESULTS AND DISCUSSION Vegetative growth of radish plant}

Fig.1 shows the variation in plant height of radish crop for various irrigation treatments at 20,40 and 60 days after planting. All the treatment show a reasonable increase in the plant height over each interval of 20 days, although the increment in the plant height after 60 days was observed to be highest for the total sewage water irrigated treatment $\left(\mathrm{T}_{4}\right)$. The increase was observed to be minimum for the treatment $\left(T_{1}\right)$ after 60 days as compared to the central plot $\left(\mathrm{T}_{0}\right)$. The maximum height attained by the plants in fully sewage water irrigated treatments $\mathrm{T}_{4}$ was found to be $13.13 \mathrm{~cm}$ followed by $\mathrm{T}_{3}(12.64 \mathrm{~cm})$ and $\mathrm{T}_{2}(11.57 \mathrm{~cm})$ respectively after 20 days. A similar trend was observed at 40days and at 60 days after the growth of radish plant and the maximum height was observed for the treatment $\mathrm{T}_{4}(25.43 \mathrm{~cm})$ followed by $\mathrm{T}_{3}(23.89 \mathrm{~cm})$ as compared to control plot $\mathrm{T}_{0}$ $(19.66 \mathrm{~cm})$. It is evident from the Figure that there is not much difference in the plant heights of all the treatments after first irrigation but the difference was much higher after the final irrigation. The results were found to be significant due to the treatments and the critical difference $\left(\mathrm{C}_{\mathrm{DT}}\right)$ value was observed as $0.4074,0.1658$ and 0.0428 at 20,40 and 60 days respectively.

\section{Yield components of radish crop}

The data of yield components for mature radish (root) crop such as length, girth and average yield were recorded at the time of harvest and presented in Figures 2, 3 and 4 respectively.

Fig 2 shows the variation in length of radish crop by the various irrigation treatments after 60 days of growth. The Figure clearly indicates that the maximum length of radish was achieved in $\mathrm{T}_{4}$ and the lowest in $\mathrm{T}_{1}$ as compared to the control plot $\left(\mathrm{T}_{0}\right)$. The maximum length of radish was attained in plot $\mathrm{T}_{4}(28.47 \mathrm{~cm})$ and the lowest in $\mathrm{T}_{1}(21.50 \mathrm{~cm})$ as compared to con- 
trol plot $\mathrm{T}_{0}(18.42 \mathrm{~cm})$. The maximum increase in length was found for $\mathrm{T}_{4}(54.56 \%)$ plot over the control plot $\mathrm{T}_{0}$. The result was found significant due to treatment and critical difference $\left(C_{D T}\right)$ value was observed as 0.2478

Fig 3 shows the variation in girth of radish root for various irrigation treatments after 60 days of growth. The increase was observed to be maximum for treatment $\mathrm{T}_{4}$ as compared to control plot $\left(\mathrm{T}_{0}\right)$. The maximum girth was found for the treatment $\mathrm{T}_{4}(16.66 \mathrm{~cm})$ followed by $\mathrm{T}_{3}$ $(15.05 \mathrm{~cm}), \mathrm{T} \mathrm{T}_{2}(13.66)$ and $\mathrm{T}_{1}(11.86 \mathrm{~cm}) \mathrm{re}-$ spectively. The increase in root girth in percent- age was found to be $48.08 \% 33.77 \%, 21.42 \%$ and $5.42 \%$ for $\mathrm{T}_{4}, \mathrm{~T}_{3}, \mathrm{~T}_{2}, \mathrm{~T}_{1}$ respectively over control plot $\left(\mathrm{T}_{0}\right)$. The result was found to be significant due to treatment and critical difference $\left(\mathrm{C}_{\mathrm{DT}}\right)$ value was found to be 0.142 .

Quality of water and marketable yield component

Sewage treated water at varying quality levels was applied to winter radish crop and its mixture with tube-well had a significant effect on yield as presented in Figure 4. As evident the sewage and tube-well water combination significantly influenced the mean root length, girt

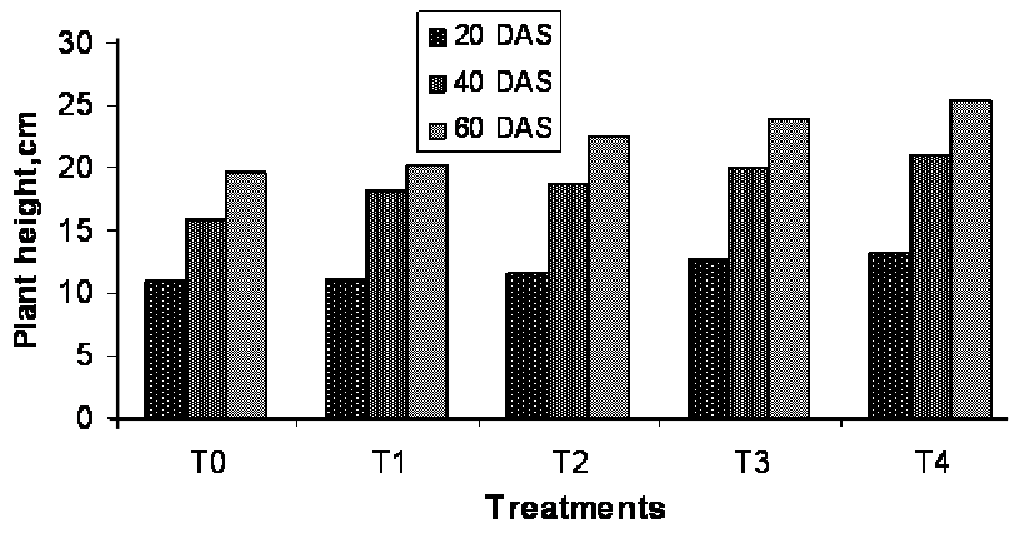

Fig. 1: Variation in Plant height of Radish at different time interval for various treatment

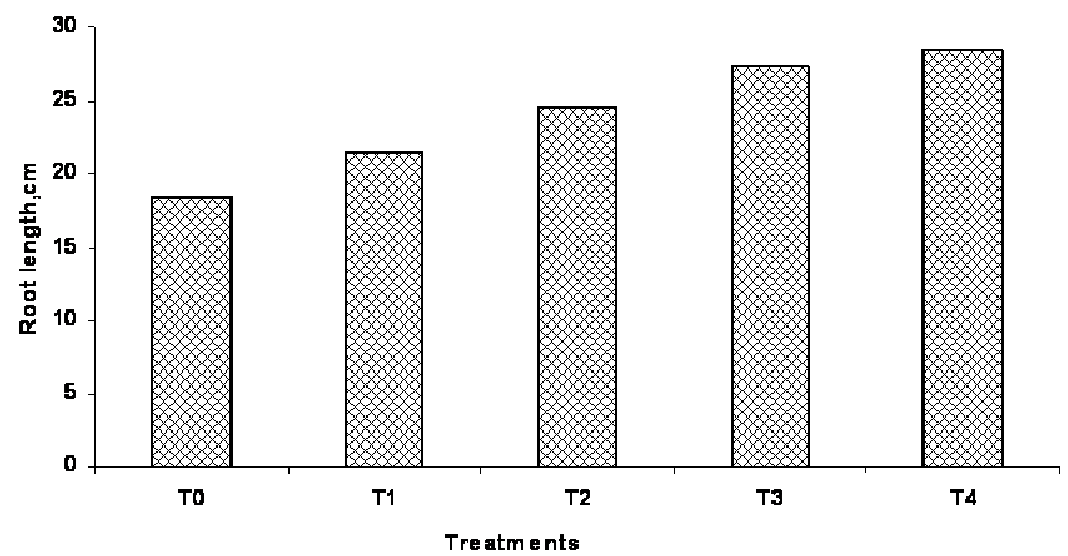

Fig. 2: Variation in Root length of Radish for various treatments 


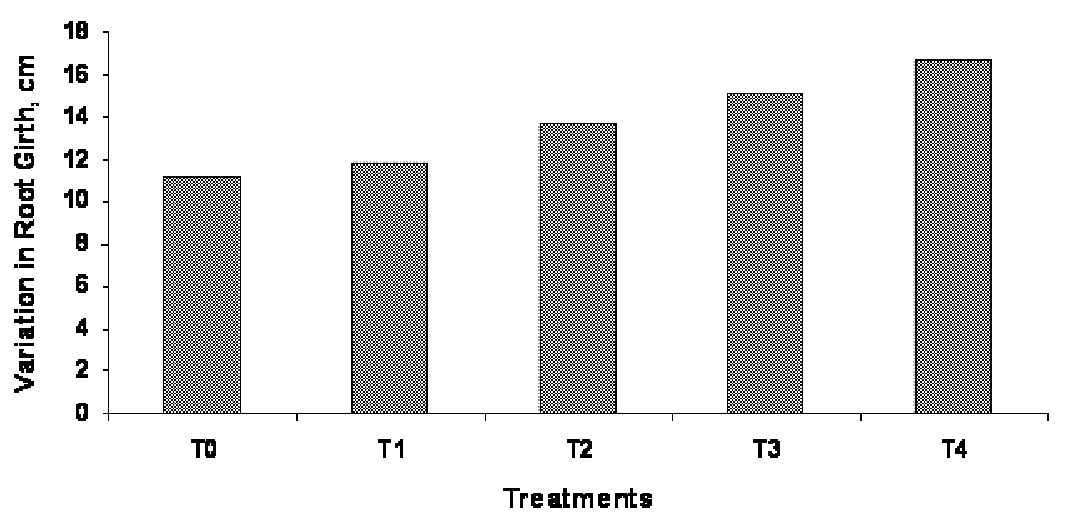

Fig. 3: Variation in Root Girth of Radish for various treatments

and other yield components of the crop. Tubewell water and its combination with sewage at various levels improved marketable mean yield of crop from 26.36 to $34.88 \mathrm{t} / \mathrm{ha}$. The maximum marketable yield was observed for untreated sewage $\left(\mathrm{T}_{4}\right)$ and the minimum marketable yield was recorded for the plants irrigated by tube well water $\left(\mathrm{T}_{0}\right)$.No significant difference was recorded between $T_{1}(27.65 t / h a)$ and $T_{2}(29.75 t /$ ha).

Similar findings were reported by poltseny,1974;Neilson,1989;Mani,1990; Al-Naksha -bandi,1997.Poletseny(1974) reported an increase in yield of maize with increase in sewage irrigation.Nielson(1989) reported higher yields of vegetables irrigated with municipal waste water.Mani(1990) also found that there was considerable increase in yield of green vegetable (spinach) matter after using the sewage water for irrigation and has found that grain and straw yield of wheat increases with the application of sewage sludge. Al-Nakshabandi (1997) reported that the egg plant yield under treated effluent was twice the average egg plant production under fresh water irrigation.

Quality of water and economic return The cost of production of radish crop grown with various treatments of irrigation water is presented in Table 1.It is evident that the cost of production per hectare was observed to be minimum (US\$ 521.26/ha) with untreated sewage $\left(\mathrm{T}_{4}\right)$ irrigation. Gross and net cost of production increase irrigating with mixture of tube -well water with sewage. The maximum cost of production was recorded using tube-well water $\left(\mathrm{T}_{0}\right)$.The gross return per hectare was maximum with sewage irrigation (US\$ 4152.38/ha) whereas the minimum was recorded with fresh water $\mathrm{T}_{0}$ (US\$ 3138.09/ha).

Table 1 show that there is a significant difference in cost of production using tube-well water and fully sewage irrigated crop. The benefit cost ratio has shown a significant gain with sewage and tube well water mixed with sewage irrigation. Similar results were reported by some researchers under variety of irrigation system and regimes, soil, crop and climatic conditions (Shrivastava 1994,Singh 1997).The microbiological testing for radish plant grown under various treatments shows that there is significant increase in the counts of pathogens and fungi above the water having 50\% sewage water content although the presence of fungi and bacteria were remarkably lower at $50 \%$ and $25 \%$ sewage water irrigated plots. 


\section{CONCLUSION}

The study shows that the content of sewage in irrigation water directly affects the yield components of radish crop and significantly increases the vegetative growth. The maximum net return was estimated for the treatment $T_{4}$ and the minimum for treatment $\mathrm{T}_{1}$. Benefit cost ratio was found to decreased with the increase in volume of tube-well water. The experimental results show that irrigation with $100 \%$ sewage water irrigation provides significantly higher marketable yield of radish.50\% and $25 \%$ sewage water can successfully be used for irrigation without harm.

\section{REFERENCES}

Al-Nakshabandi, G.A., Saqqar, M.M., Shatanawi, M.R., Fayyd, M. and AlHorani, H. (1997). Some environmental problems associated with the use of treated waste water for irrigation in Jordan, $J$. Agric. Water Management, 34: 81-94.

Mani,D. (1990). Research paper on "Utilization of sewage water with Farm Yard Manure and Mussoorie Rock Phosphate". Vigyana Parishad Anusandhan Patrika, 36(3): 188190.

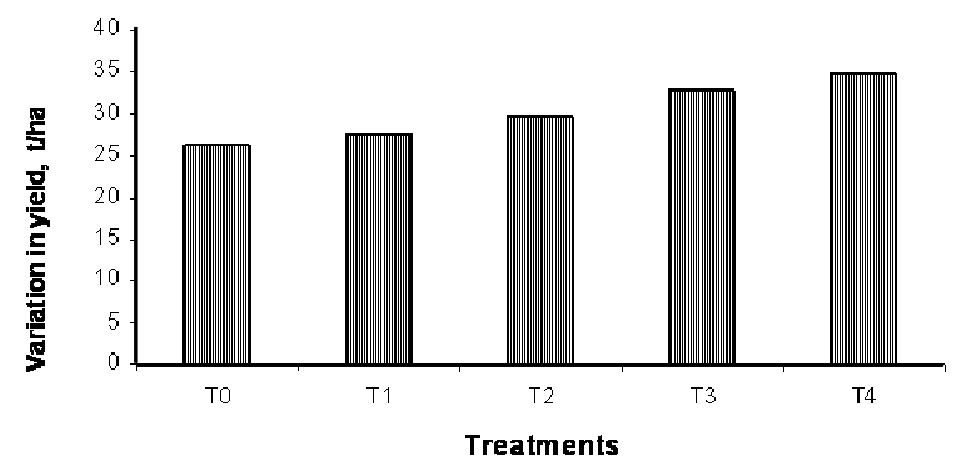

Fig. 4: Variation in Yield of Radish for various treatments

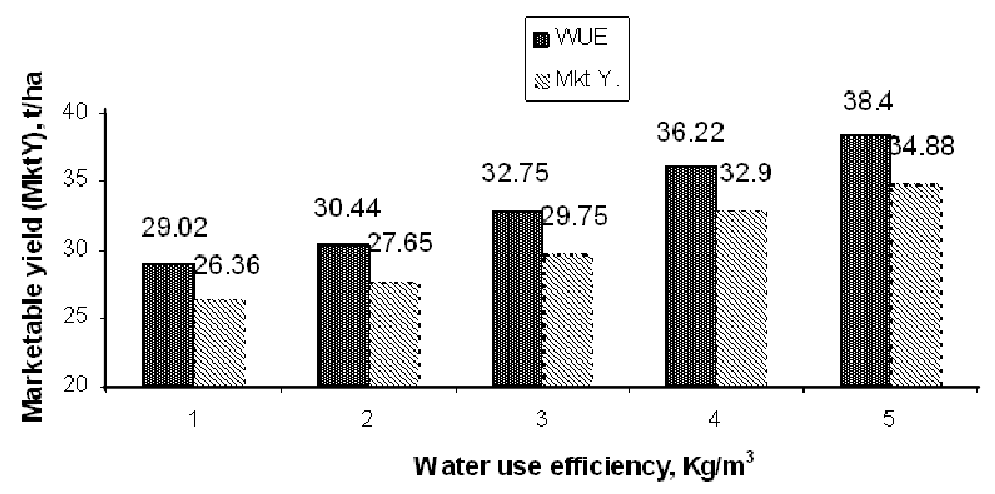

Fig. 5: Variation of marketable yield Mkt. Y) with water use efficiency 
Klimo, E. and Feketa (1990). The effect of sewage water irrigation on the soil, the vegetation and the ground water. Indian J. Agric. Chem. 23: 19-25.

Neilsen, G.H., Stevenson, D.S. Fitzpatrick, J.J. and Brownlee, C.H. (1989). Yield and plant nutrient content of vegetables trickleirrigated with municipal waste water. $J$. HORT SCIENC, 24(2): 249-252.

Poletseny, H. (1974). "Effect of sewage sludge on yield of maize grain". Field crop Abs. (1974-75).

Sadan, E. and Haruvy, N. (1994). Subsidy by irrigation water-20 years backwards and 20 years forwards. Water and Irrigation, 335: 7-9.
Singh, S., Ram, M., Ram, D. Sharma, S. and Singh, D.V. (1997). Water requirement andproductivity of palmarosa on sandy loam soil under subtropical climate. Agric. Water Manage. 35: 1-10.

Srivastava, P.K., Parikh, M.M. Swami, N.G. and Raman. S. (1994). Effect of irrigation and mulching on tomato yield. Agric. Water Manage. 25: 179-184.

Tumarkar, A.S. and Shinds, G.B. (1986). Interaction of $\mathrm{Cd}, \mathrm{Pb}$, effect of growth yield and content of $\mathrm{Cd}, \mathrm{Pb}$ in Barley (Hordeum vulgare). Indian J. Environ. Hlth., 8(3): 235243. 